\title{
THE CIVIL LAW REVIEW OF THE ROLE OF JOINT VILLAGE- OWNED BUSINESS ENTITIES (BUM DESA BERSAMA) AS THE SUBJECT OF CIVIL LAW
}

\author{
SITTA SARAYA \\ Faculty of Law, Bachelor Degree Program \\ Universitas Selamat Sri (UNISS) Kendal \\ Jawa Tengah, Indonesia \\ sitta@uniss.ac.id \\ sittalaw@gmail.com
}

\begin{abstract}
Village development in Indonesia demands a growing system of regulations both in the field of village development and its economy so that since the enactment of Law Number 6 of 2014 concerning Villages, Village-Owned Enterprises (BUM Desa) have emerged to support economic development and development of a village in Indonesia. BUM Desa is a Legal Entity that can carry out legal actions to manage capital and assets owned, provide general public services in the form of drinking water management, village waste management, management of barns, making ponds, managing plantation products and livestock products, utilizing tourism potential into villages tourism and other business activities that involve the active role of independent village communities, establish partnerships and cooperation with other parties, both individuals and other legal entities such as Limited Liability Companies, CVs and so on. The purpose of this study is to find out the role of the role of the Joint Village Business Entity as the subject of Civil Law in carrying out various legal actions including cooperating in various fields with other business entities incorporated.
\end{abstract}

Keywords : Civil Law, Joint Village Owned Enterprises (BUM Desa Bersama), Subjects of Civil Law

\section{INTRODUCTION}

The existence of a Village-Owned Enterprise (BUM Desa), which is one of the economic institutions of rural communities, is expected to be able to provide useful contributions to the village and increase the village's income sources. The existence of a Village-Owned Enterprise needs to get legal legality. In Law No. 6 of 2014 concerning the Village and its implementing regulations, namely Government Regulation No. 43 of 2014 (PP concerning Villages) states that Village-Owned Enterprises (BUM Desa) are business entities whose entire or part 
of their capital is owned by the village through direct participation originating from separated village assets to manage assets, services, and businesses. others for the greatest welfare of the village community. ${ }^{1}$ In this research, analyzing the formation of BUM Desa Bersama which is a combination of several BUM Desa, also the role of BUM Desa and BUM Desa Bersama as legal subjects in carrying out civil law actions in this case agreements with other business entities incorporated. Civil Law is a series of legal regulations that regulate the relationship of legal subjects (people and legal entities) one with another legal subject by emphasizing the personal interests of the legal subject. ${ }^{2}$ Discussing about BUM Desa and BUM Desa Bersama, based on Permendesa No. 4 of 2015 article 6, it was said that two or more villages could establish a BUM Desa together with the one agreed upon through inter-village consultation facilitated by inter-village cooperation bodies consisting of: ${ }^{3}$ (1) Village government; (2) BPD member; (3) Village community institutions (LKMD); (4) Other village institutions; (5) Public figure.

Based on the provisions of Article 6 of Permendesa Number 4 of 2015, it can be concluded that several villages can make one BUM Desa managed jointly or commonly called a Joint Village Owned Enterprise (BUM Desa Bersama). With the existence of BUM Desa and BUM Desa Bersama, it is necessary empowering village communities. Village Community Empowerment is an effort to develop community independence and prosperity by increasing knowledge, attitudes, skills, behaviors, abilities, awareness, and utilizing resources through the establishment of policies, programs, activities, and assistance that are in accordance with the essence of the problem and priority needs of the village community. 4

For more details, here there are several regulations or legal basis for the establishment of Village-Owned Enterprises (BUM Desa):

\footnotetext{
Article No 1 point 6 Law Number 6 of 2014 concerning Villages (UU Desa)

Komariah, 2002, Hukum Perdata, Malang: UMM Press. page 4

Article 6 Permendesa Nomor 4 Year 2015

Article 1 point 12 Law Number 6 of 2014 concerning Villages (UU Desa)
} 


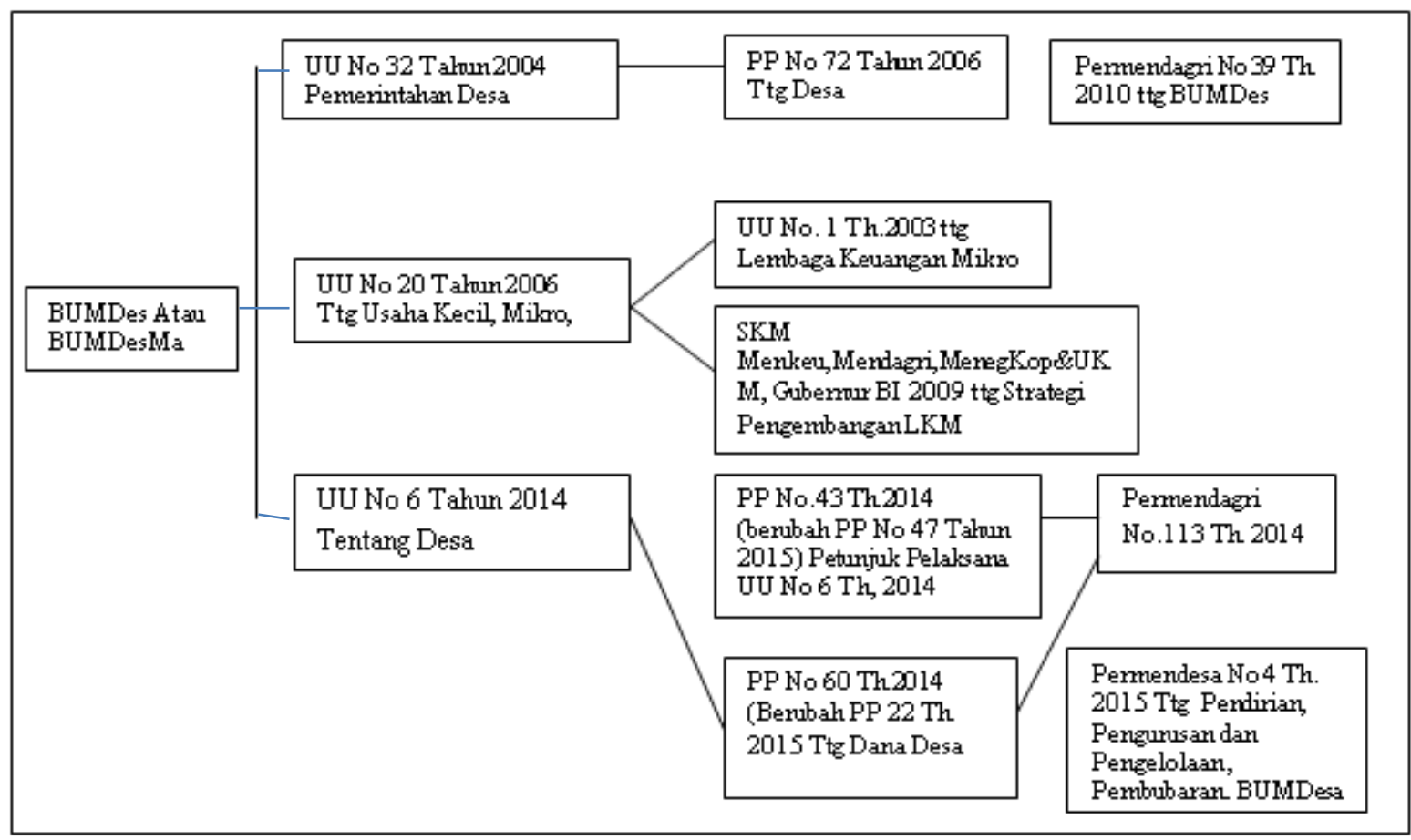

Information :

Chart 1 Legal Basis of Village-Owned Enterprises (BUM Desa) and Joint Village Owned Enterprises (BUM Desa Bersama)

\section{RESEARCH METHODS}

The type of research method in this study is normative juridical. Normative juridical law research is a process to find a rule of law, legal principles, and legal doctrines faced. ${ }^{5}$ In this research the law was identified as a rule norm or Law (UU), Government Regulation (PP). The legal approach is carried out by examining all the rules of the Law and regulations relating to the legal issues being addressed. ${ }^{6}$ The Legal materials used in this research are in the form of primary legal material and secondary legal material. Primary legal materials consist of the Civil Code, Law No 6 of 2014 concerning Villages (UU Desa) and Law Number 40 of 2007 concerning Limited Liability Companies (UUPT), Government Regulation Number 43 of 2014 ( PP Desa), Village Minister

5 Peter Mahmud Marzuki. 2015. Penelitian Hukum, Surabaya. Kencana. page 35

6 Ibid 
Regulation, Development of Disadvantaged Regions, and Transmigration of the Republic of Indonesia Number 4 of 2015 concerning Establishment, Management and Management, and Dissolution of Village-Owned Enterprises. Secondary legal material is obtained by means of library research through books, journals, research results that are relevant to the research of the author. Primary legal materials were collected by interviewing the Joint Village Owned Enterprise (BUM Desa with "Sari Plasma Petik") and PT Fruit Ing Indonesia Tbk Surabaya.

\section{RESULTS AND DISCUSSION}

a. The Position of Joint Village Owned Enterprises (BUM Desa Bersama) in Civil Law

In studying civil law concerning the subject of civil law is known 2 (two) Civil Law Subjects namely: ${ }^{7}$

1) Person.

In law, orang (persoon) means the bearer of rights or subjects in the law. As we say, a person is said to be a legal subject (carrier of rights), starting from his birth and ending when he dies. In fact, if needed (such as in terms of inheritance), it can be counted since he was in the womb, provided he was born alive.

2) Legal entity.

Subekti said that in addition to people, bodies or associations also have rights and carry out legal actions like a human being. The bodies or associations have their own wealth, participate in legal traffic with their management intermediaries, can be sued, and can also sue before the judge.

In this study, the existence of a Village-Owned Business Entity or a Joint Village-Owned Business Entity (BUM Desa Bersama) needs to obtain legal legality. In Law No. 6 of 2014 concerning Villages and its implementing regulations, namely Government Regulation No. 43 of 2014 (PP concerning Village) states that Village-Owned Enterprises (BUM Desa) are business

7 Subekti. 1992. Pokok-Pokok Hukum Perdata. Jakarta. Internusa. page 19-21. 
entities whose entire or part of their capital is owned by the village through participation directly from the village's separated wealth to manage assets, services and other businesses for the greatest welfare of the village community. ${ }^{8}$

In the provisions of Chapter X Article 87 of Law Number 6 Year 2014 concerning Villages it is regulated that: ${ }^{9}(1)$ Villages can establish a VillageOwned Business Entity called BUM Desa;(2) BUM Desa is managed with a spirit of kinship and mutual cooperation; (3) BUM Desa can run a business in the economic sector and / or public services in accordance with the provisions of the legislation.

In Article 88 of Law Number 6 Year 2014 concerning Juncto Village. Article 132 of the PP concerning the Village states that a Village-Owned Business Entity (BUM Desa) is established based on village meetings, which is then determined by the Village Head and the formation of BUM Desa with the local Village Regulation. Furthermore, in Article 135 of the PP concerning the Village, it is also stated that the initial capital of BUM Desa comes from the Village Expenditure Budget (APB Desa) which is the wealth of the village which is separated and not divided into shares. The capital owned by BUM Desa consists of: (1) Participation of Village Capital, which originates from APB Desa and others; (2) Capital Participation of Village Communities.

The position of Village-Owned Enterprises (BUM Desa) and Joint Village-Owned Business Entities (BUM Desa Bersama) is a legal entity that must have a regular organizational structure. This regular organizational structure can be seen in Article 132 of the PP concerning the Village, stating that the Manager of a Village-Owned Enterprise (BUM Desa) must at least consist of Advisors and Operational Executors. Advisers in BUM Desa's organizational structure are held by the local Village Head, while Operational Executors are individuals who are appointed and dismissed by the Village Head. As for the organizational structure of the Joint Village Owned Enterprise

8 Articlel 1 point 6 Law Number 6 of 2014 concerning Villages (UU Desa) Ibid. 
(BUM desa Bersama), it consists of a Managing Director appointed based on collective meetings from several BUM Desa representatives, then other administrators, both secretaries and treasurers and coordinators of the units also discussed together. ${ }^{10}$

Unlike the case with other legal entities such as limited liability companies, foundations or cooperatives, where all of them get their legal status or legal justification as legal entities when getting approval from the Ministry. ${ }^{11}$ In Law No. 6 of 2014 concerning Villages and the PP on Villages it is not explicitly stated that when the BUM Desa or BUM Desa Bersama are legitimate, they become a legal entity. But when viewed from Article 88 of Law Number 6 Year 2014 concerning the Village of Juncto Article 132 PP concerning the Village which states that "The establishment of BUM Desa is carried out through a village meeting and stipulated by Village regulations ", it can be concluded here that when it was ratified and a joint agreement took place at the Village Consultation then the agreement was stipulated in a Village Regulation, then the Business Entity was formed legally. Village-owned (BUM Desa) as a legal entity in the subject of civil law.

From the explanation above, it can be concluded that Village-Owned Enterprises (BUM Desa) and Joint Village Owned Enterprises (BUM Desa Bersama) are legal entities that must have characteristics as legal entities including: (1) The separation of assets between the body and the founder or member or shareholder; (2) Having wealth in his own name; (3) Having certain goals; (4) Having their own interests; (5) Can sue and be sued in court on his own behalf and (6) There is a regular organization.

From several characteristics of BUM Desa and BUM Desa Together with the above as legal entities, the wealth of BUM Desa and BUM Desa Bersama is a separate village asset, for BUM Desa Bersama, its wealth consists of the APB Desa of each Village where BUM Desanya joins BUM Desa from the

10 organizational structure BUM Desa Bersama “ Plasma Petik Sari “ Kecamatan Sukorejo, Kabupaten Kendal, Jawa Tengah.

11 http://business-law.binus.ac.id Erni Herawati. Village-Owned Business Entity, Status and Position 
Village others become BUM Desa Bersama. BUM Desa and BUM Desa Bersama have the objectives and interests set by Law No. 6 of 2014 concerning Villages, namely to develop the village economy and increase village income. BUM Desa and BUM Desa Bersama also have regular organizations that can be seen from the presence of operational advisors and implementers.

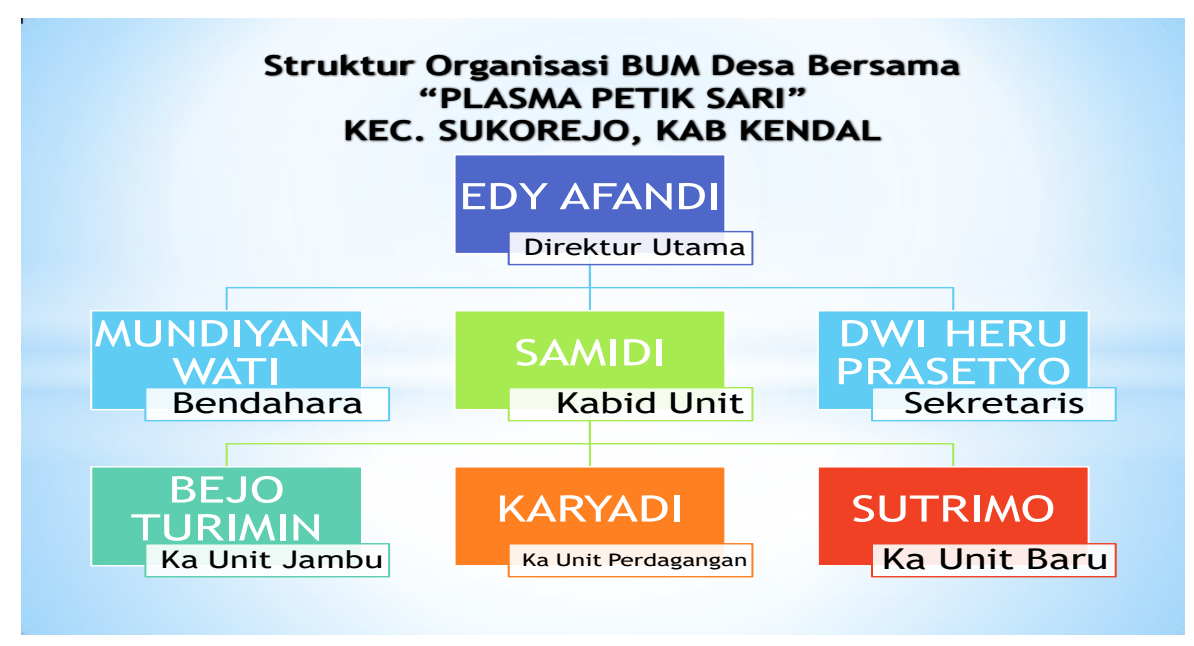

Information:

Chart 2 Examples of Organizational Structure of BUM Desa Together in Plasma Petik Sari, Sukorejo District and Patean district

\section{b. The Differences between BUM Desa, BUM Desa Bersama and BUMN}

As a public society, we need to know that BUM Desa, BUM Desa Bersama and BUMN are both legal entities. However, there are several things that distinguish between BUM Desa and BUM Desa together with other Business Entities which are both legal entities, in this case can be compared with State-Owned Enterprises.

\begin{tabular}{|c|c|c|c|}
\hline NO & DIFFERENCES & $\begin{array}{l}\text { BUM DESA AS WELL AS BUM } \\
\text { DESA BERSAMA }\end{array}$ & BUMN \\
\hline 1. & Legal Basis & $\begin{array}{l}\text { 1) Law Number 6 of } 2014 \\
\text { concerning Villages; } \\
\text { 2) Government Regulation Number } \\
43 \text { of } 2014 \text { (PP Desa); } \\
\text { 3) Regulation of the Minister of } \\
\text { Village, Development of } \\
\text { Disadvantaged Regions, and } \\
\text { Transmigration of the Republic } \\
\text { of Indonesia Number } 4 \text { of } 2015 \\
\text { concerning Establishment, }\end{array}$ & $\begin{array}{l}\text { Law No. } 19 \text { of } \\
2003 \text { concerning } \\
\text { State-Owned } \\
\text { Enterprises }\end{array}$ \\
\hline
\end{tabular}




\begin{tabular}{|c|c|c|c|}
\hline & & $\begin{array}{l}\text { Management and Management, } \\
\text { and Dissolution of Village- } \\
\text { Owned Enterprises. }\end{array}$ & \\
\hline 2. & Definition & $\begin{array}{l}\text { BUM Desa is a business entity } \\
\text { whereby all or part of its capital is } \\
\text { owned by the village through direct } \\
\text { participation originating from } \\
\text { separated village assets in order to } \\
\text { manage assets, services and other } \\
\text { businesses for the greatest welfare } \\
\text { of the village community. BUM } \\
\text { Desa Bersama is a combination of } \\
\text { several BUM Desa which later } \\
\text { became a unit. }\end{array}$ & $\begin{array}{l}\text { State-Owned } \\
\text { Enterprises } \\
\text { (BUMN) are } \\
\text { business entities } \\
\text { whose capital is } \\
\text { wholly or partly } \\
\text { owned by the } \\
\text { government. }\end{array}$ \\
\hline 3. & $\begin{array}{l}\text { Capital and } \\
\text { Assets }\end{array}$ & $\begin{array}{l}\text { Village Revenue and Expenditure } \\
\text { Budget (APB Desa) }\end{array}$ & State \\
\hline 4. & Objectives & $\begin{array}{l}\text { To increase the village's income } \\
\text { source and strengthen the economic } \\
\text { sector in the village, improve the } \\
\text { welfare of the village community } \\
\text { (profit-oriented, namely obtaining } \\
\text { profits and benefits) by opening } \\
\text { opportunities for the village } \\
\text { community to take part in the } \\
\text { progress of the village and the } \\
\text { economic welfare of the community } \\
\text { itself). }\end{array}$ & $\begin{array}{l}\text { Profit Oriented, } \\
\text { Earn Profit }\end{array}$ \\
\hline 5. & Person in Charge & $\begin{array}{l}\text { The Director or can be referred to as } \\
\text { the Chair with the assistance of the } \\
\text { Advisor in this case the Village } \\
\text { Head }\end{array}$ & $\begin{array}{l}\text { Director } \\
\text { BUMN }\end{array}$ \\
\hline
\end{tabular}

Information: Table the Differences between BUM Desa, BUM Desa Bersama and BUMN

c. The Role of Joint Village Owned Enterprises (BUM Desa Bersama) as Subjects of Civil Law

In Law No. 6 of 2014 concerning Villages and its implementing regulations, namely Government Regulation No. 43 of 2014 (PP concerning Village) states that Village-Owned Enterprises (BUM Desa) are business entities whose entire or part of their capital is owned by the village through participation directly from the village's separated wealth to manage assets, 
services and other businesses for the greatest welfare of the village community. $^{12}$

Definition of Civil Law Subjects is a person or party whether a legal entity or a legal entity that carries out legal actions. Legal actions here that give rise to legal relations if they are related to civil law are engagement laws as listed in Book III of the Civil Code (KUH Perdata) concerning Engagement.

Sutoro Eko et al. Have stated that 6 (six) types of businesses that can be held by BUM Desa can be classified as follows: ${ }^{13}$

\section{Serving}

BUM Desa runs a "social business" that serves citizens, which is able to do public services to the community. An example of a type of Serving business is the village water supply business, both clean water management and management of drinking water (distilled), village electricity business, food storage, etc. Some villages also provide services in the form of waste management.

\section{Banking}

BUM Desa runs a "money business". For example, forming a cooperative or Village Bank and also a Village Community Credit Institution. This business is very popular among rural people who need loan funds for business capital with low interest loans from individuals who work as loan sharks or other conventional banks. Some villages also implement banking business by establishing a Waste Bank.

\section{Renting}

BUM Desa runs a rental business. Among them are tractor rentals, party buildings, party utensils, houses, shops etc.

\section{Brokering}

BUM Desa is an intermediary institution or term broker that connects agricultural commodities with markets, or some other services such as electricity services, PDAM payments, telephone credit and several others.

Articlel 1 point 6 Law Number 6 of 2014 concerning Villages (UU Desa)

13 Policy Paper "Membangun Badan Usaha Milik Desa Yang Mandiri, Kokoh Dan Berkelanjutan" published by FPPD and ACCES at January 2014 


\section{Trading}

BUM Desa runs certain businesses and produces certain items to meet people's needs, including the production of ice cubes, agricultural products etc. In some BUM Desa produces processing coffee, tea and some processed foods that are packaged for souvenirs.

\section{Holding}

BUM Desa as a joint venture or as a parent of units in the village, where the units of each stand alone are regulated and synergized by BUM Desa to grow a joint business. The holding business that is currently developing is a Tourism Village in various tourist destinations which is a tourist attraction of a village or raises the potential of a village.

In connection with the activities and roles carried out by the JointlyOwned Village Enterprises, the authors conducted a study on the role of BUM Desa Bersama in BUM Desa Bersama "Plasma Petik Sari" consisting of 7 (seven) BUM Desa. The study consisted of several joint BUM Desa. BUM Joint Sari Plasma Village located in Sukorejo Subdistrict, Kendal Regency, becomes BUM Desa Bersama, a pilot that is considered successful in developing the Getas Merah Guava business and cooperating with a Collective Labor Agreement with private companies with legal entities, namely PT. Fruit Ing Indonesia Tbk Surabaya.

The following is a table of several villages incorporated in BUM Desa Bersama "Plasma Petik Sari" Sukorejo and Patean Subdistricts, as well as management planning of red brittle guava horticulture plants:

\section{LUAS LAHAN DAN HASIL PANEN DALAM Kg}

\begin{tabular}{|c|c|c|c|c|c|c|c|}
\hline \multirow[b]{2}{*}{ NO } & \multirow[b]{2}{*}{ DESA } & \multirow{2}{*}{$\begin{array}{l}\text { JUMLAH } \\
\text { PETANI }\end{array}$} & \multirow{2}{*}{$\begin{array}{l}\text { LUAS } \\
\text { AREAL } \\
(\mathrm{Ha})\end{array}$} & \multirow{2}{*}{$\begin{array}{l}\text { JUMLAH } \\
\text { POHON } \\
\text { (Batang) }\end{array}$} & \multicolumn{3}{|c|}{ HASIL PANEN } \\
\hline & & & & & $\begin{array}{c}1 \text { Petik } \\
\text { (2-3 Kg/Phn) }\end{array}$ & $\begin{array}{c}1 \mathrm{Mggu} \\
2 \times \text { Petik }\end{array}$ & $\begin{array}{c}1 \text { Bln } \\
8 \times \text { Petik }\end{array}$ \\
\hline 1 & KALIPAKIS & 284 & 56,26 & 15.628 & 45.321 & 90.642 & 362.568 \\
\hline 2 & PESAREN & 208 & 46,38 & 12.883 & 36.072 & 72.144 & 288.576 \\
\hline 3 & TRIMULYO & 164 & 30,73 & 8.536 & 24.754 & 49.508 & 198.032 \\
\hline 4 & BRINGINSARI & 300 & 60,82 & 17.378 & 45.183 & 90.366 & 361.464 \\
\hline 5 & PLOSOSARI & 153 & 31,66 & 9.313 & 27.939 & 55.878 & 223.512 \\
\hline 6 & PAKISAN & 167 & 36,12 & 10.033 & 29.096 & 58.192 & 232.768 \\
\hline 7 & MLATIHARJO & 154 & 33,35 & 9.264 & 26.402 & 52.804 & 211.216 \\
\hline & JUMLAH & 1430 & 295,326 & 83.035 & 234.767 & 469.534 & 1.878 .136 \\
\hline
\end{tabular}


The Collective Labor Agreement between BUM Desa and Sari Plasma with PT Fruit Ing is an Agreement on Management of Red Getas Guava Horticulture with Agreement Number: 019.2 / 003 / BUMDESMA / P2S / III / 2018 or Number: FI / 02 / III / 2018 / PKS. This signing was held on Wednesday, March 7, 2018 by the Director of BUM Desa with Mr. Edy Afandi as the first party and Director of PT Fruit Ing Indonesia Mr. Dr. Drs. Ec. Iwan Winardi MM as the second party. While as a witness is the Regent of Kendal, Mrs. Dr. Mirna Annisa, M.Sc and Ceo PT Fruit Ing Mr. Calvin Andryan.

The Collective Labor Agreement in the above research contains several articles and is in accordance with the legal requirements of the agreement ${ }^{14}$ of course, both parties agreed on the agreement elements: ${ }^{15}$ (1) There is an agreement from two parties or more; (2) The agreement reached depends on the parties; (3) The wishes or goals of the parties for the emergence of legal consequences; (4) Legal consequences for the interests of one and at the expense of the other party or reciprocity; (5) Made by observing statutory provisions

\section{CONCLUSION}

From the description above, BUM Desa Bersama is a Legal Entity in accordance with Law Number 6 of 2014 concerning Villages, although it is explicitly not explained, but because BUM Desa and BUM Desa are formed by the local Village based on Village Consultations and then strengthened by Village Regulation, so that legally that BUM Desa or BUM Desa Bersama are Legal Entities. BUM Desa and BUM Desa Bersama are also subjects of civil law who are capable of carrying out legal actions so as to produce legal relations in this case the Engagement Law. As the subject of a civil law, BUM Desa Bersama has the right to enter into an agreement with the source of the Civil Code.

14 Article 1320 Civil Code : (a) both parties are Agree; (b) having competenty to do the law;(c) A certain thing; and; (d) reason that is lawful

15 Herlien Budiono. 2015.Peran Badan Usaha di Luar Perseroan TerbatasDalam Memberikan Kontribusi Bagi Peningkatan ekonomi Nasional Dalam Kumpulan Tulisan Hukum Perdata di Bidang Kenotariatan.Citra Aditya Bhakti. Bandung. Page. 120 


\section{BIBLIOGRAPHY}

Budiono Herlien, 2015, Kumpulan Tulisan Hukum Perdata di Bidang Kenotariatan. Bandung: Citra Aditya Bhakti

Marzuki, Peter Mahmud, 2011, Penelitian Hukum, Surabaya : Kencana

Mulyoto,2012, Perjanjian Teknik, Cara Membuat dan Hukum Perjanjian Yang Harus Dikuasai. Yogyakarta: Cakrawala Media

Mulyoto, 2016, Legal Standing. Yogyakarta: Cakrawala Media

Subekti Henricus Dan Mulyoto, 2017, Badan Usaha Pengertian,Bentuk Dan Tata Cara Pembuatan Akta-Aktanya. Yogyakarta: Cakrawala Media

Eko Suroto, etc. Januari 2014, Policy Paper "Membangun Badan Usaha Milik Desa Yang Mandiri, Kokoh Dan Berkelanjutan” Jakarta: kerjasama FPPD dengan ACCES

Suteki and Galang Taufani, 2017, Metodologi Penelitian Hukum (Filsafat,Teori Dan Praktik), Depok: Raja Grafindo Persada

\section{Regulations}

Civil Code (KUH Perdata)

Law Number 6 of 2014 concerning Villages (UU Desa)

Government Regulation Number 43 of 2014 (PP Desa);

Regulation of the Minister of Village, Development of Disadvantaged Regions, and Transmigration of the Republic of Indonesia Number 4 of 2015 concerning Establishment, Management and Management, and Dissolution of Village-Owned Enterprises.

Law No. 19 of 2003 concerning State-Owned Enterprises

\section{Internet}

http://business-law.binus.ac.id Erni Herawati. Village-Owned Business Entity, Status and Position 